\section{Interaction between Helicobacter pylori and host genetic variants in gastric carcinogenesis}

\author{
Zhi-fang Jia ${ }^{\ddagger 1,2}$, Song-ling Zhang ${ }^{\ddagger, 3}$, Xue-yuan $\mathrm{CaO}^{4}$, Bao-sen Zhou² \& Jing Jiang ${ }^{*, 1}$
}

Helicobacter pylori (H. pylori) is the definite carcinogen of gastric cancer. H. pylori infection induces chronic inflammation, causes DNA damage and aberrant methylation of genes and these pathways are involved in H. pylori-related gastric carcinogenesis. Polymorphisms of the genes involved in these pathways could alter susceptibility to gastric cancer. In this mini review, we focused on the role of polymorphisms in these genes on the susceptibility to gastric cancer, with a particular emphasis on their possible interactions with $\mathrm{H}$. pylori infection. We found that many studies on this theme did not simultaneously report $H$. pylori infection and the interactions remained inconclusive.

First submitted: 27 October 2015; Accepted for publication: 25 May 2016; Published online: 21 June 2016

Gastric cancer (GC) is the fifth most common cancer [1], and because of its unfavorable prognosis even with radical tumorectomy and advances in molecule targeted therapy [2], it ranks as the third cause of cancer-related death worldwide [1]. The incidence of GC is geographically varied, with a high prevalence in eastern Asia, central and eastern Europe and Central and South America [1]. Even within eastern Asia, the incidence of GC has a tendency to decrease from north to south [3]. Several factors, such as Helicobacter pylori (H. pylori) infection [4], the intake of salted and nitrated foods [5] and cigarette smoking [6], have been identified to be associated with gastric carcinogenesis, of which $H$. pylori infection is the most remarkable.

$H$. pylori infection is associated with various gastric diseases, including asymptomatic gastritis, peptic ulcer disease and gastric neoplasm [7]. Over half of the world's population is infected with $H$. pylori and 1 to $3 \%$ of the infected individuals develop gastric cancer, making $H$. pylori the most common etiologic agent of GC [7,8]. Although numerous studies have focused on the pathogenesis of $H$. pylori-induced gastric cancer, the exact underlying mechanism is still unclear (Figure 1).

Both the bacteria and host contribute to gastric carcinogenesis. Bacteria virulence factors such as CagA (cytotoxin-associated gene $\mathrm{A}$ ) and its pathogenicity island (CagPAI), and VacA (vacuolating cytotoxin A), are associated with the pathogenicity of $H$. pylori [7]. On the other hand, host genetic variants, mainly the single nucleotide polymorphisms (SNPs), could modify this effect as demonstrated by the fact that only a small proportion of individuals with the known risk factors develop gastric cancer and that individuals infected with $H$. pylori display various outcomes $[7,9]$.

\section{KEYWORDS}

- DNA damage $\bullet$ gastric cancer $\bullet$ Helicobacter pylori • inflammation - methylation - polymorphism 


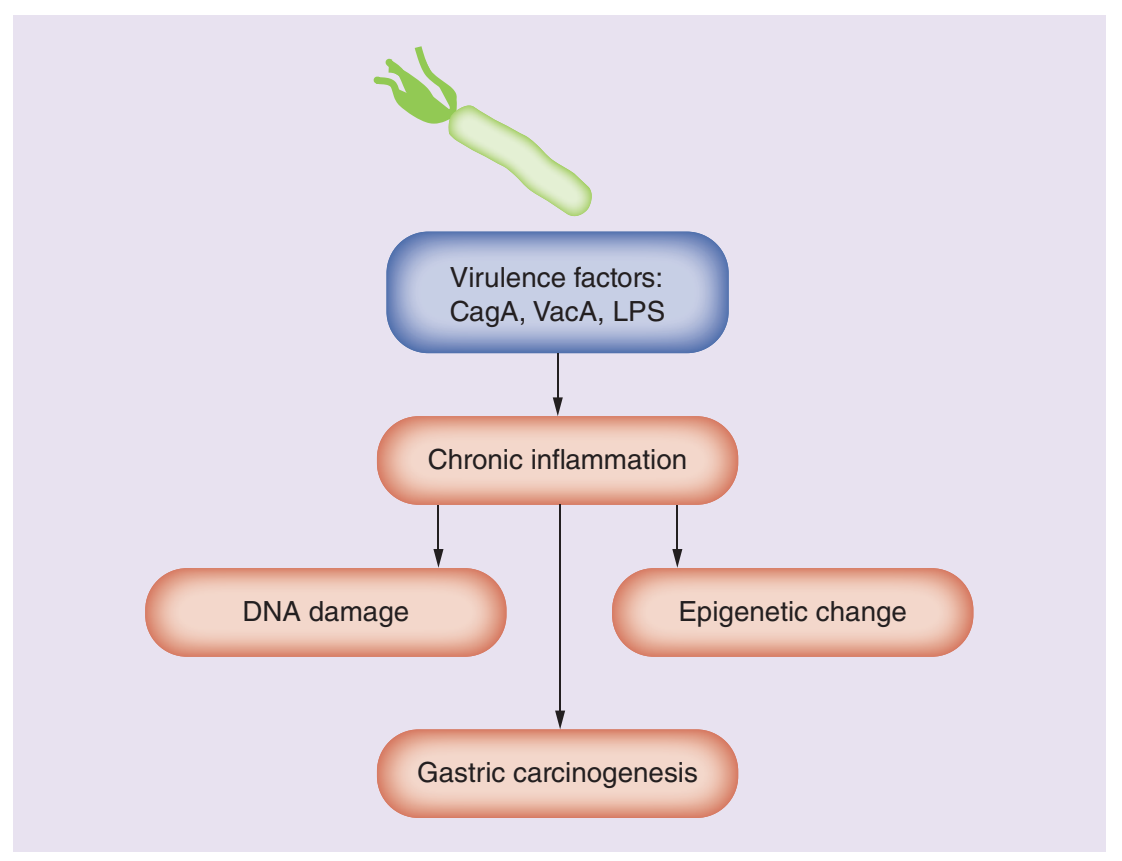

Figure 1. The schematic illustration of Helicobacter pylori-related gastric cancer. CagA: Cytotoxin-associated gene A; LPS: Lipopolysaccharide; VacA: Vacuolating cytotoxin A.

\section{- IL-1 $\beta$ \& IL-1RN}

$I L-1 \beta$ and its endogenous receptor antagonist $(I L-1 R N)$ cluster on chromosome $2 \mathrm{q}$. IL-1 $\beta$ is upregulated after $H$. pylori infection. IL-1 $\beta$ not only plays a central role in initiating and amplifying the inflammatory response to the infection, but also inhibits gastric acid secretion, which facilitates the colonization of $H$. pylori and contributes to gastric gastritis, atrophy and increasing the risk of GC [11]. A transgenic mouse model that overexpresses IL- $1 \beta$ specifically in the stomach shows less production of gastric acid and severe gastritis followed by gastric atrophy, intestinal metaplasia, dysplasia and adenocarcinomas. Moreover, this process can be accelerated by $H$. pylori infection and inhibited by IL1-RN [12].

El-Omar et al. first reported that the polymorphisms of $I L-1 \beta$ and $I L-1 R N$ were associated with the risk of hypochlorhydria in the H. pylori-infected first-degree relatives of GC cases, and GC risk [13]. The T allele of $I L-1 \beta$ 31C/T (rs1143627), which involves a TATA box in the promoter region of the $I L-1 \beta$ gene, is associated with hypochlorhydria and higher GC risk (odds ratio [OR]: 1.9; 95\% CI: 1.5-2.6). A similar association is showed for $I L-1 \beta-511 \mathrm{C} / \mathrm{T}$ (rs16944) which is in complete disequilibrium with $I L-1 \beta-31 \mathrm{C} / \mathrm{T}$. Another variant with a variable number of 86-bp tandem repeats (VNTR) in the second intron of $I L-1 R N$ also shows a higher risk of GC (for $I L-1 R N^{*} 2 /^{*} 2$ with two repeats, OR: 3.7; 95\% CI: 2.4-5.7) [13]. They then confined these associations to the noncardia GC [14]. Machado et al. then repeated the positive association in the intestinal-type GC, and only in the intestinal type but not in the diffuse or atypical type [15]. They also showed a synergic effect between $H$. pylori and genetic variations in that the combined effects of the bacterial virulence factors of $H$. pylori (cagA positive, VacA s1 and VacA m1) and the $I L-1 \beta$ or $I L-1 R N$ genotypes were much higher than the virulence factors or SNPs alone for GC risk [16]. The synergic effect was plausible because $I L-1 \beta-31 \mathrm{~T} / \mathrm{T}, 511$ $\mathrm{T} / \mathrm{T}$ genotype or $I L-1 R N^{*} 2$ allele carriers with $H$. pylori infection had higher mucosal IL-1 $\beta$ levels than did carriers without infection [17]. Additionally, because IL-1 $\beta$ could amplify the inflammatory response and inhibit gastric acid secretion, these individuals had higher atrophy and gastritis scores, higher gastric juice $\mathrm{pH}$ and lower ratios of serum PG I/PG II than non$I L-1 \beta-511 \mathrm{~T} / \mathrm{T}$ or $I L-1 R N^{*} 2$ allele carriers [18]. 
Other studies, however, showed inconsistent results that include GC cases who are different in their histological types, clinical stages, anatomic sites and ethnic groups [19-39]. A meta-analysis on $I L-1 \beta-31 \mathrm{C} / \mathrm{T}$ summarized that the $\mathrm{T}$ allele was associated with increased risk of GC only in Asians (allele C vs allele T: OR: 0.86; 95\% CI: $0.73-0.98 ; I^{2}=1.8 \%$ ), and $H$. pylori infection could enhance the risk even more (allele $\mathrm{C}$ vs allele T: OR: 0.76 ; 95\% CI: $0.61-0.96 ; P^{2}=2.6 \%$ ) (Table 1) [9]. This conclusion should be updated as this meta-analysis only included studies from 1990 to 2006, and many studies have been published since then [25,28,35-36,40-50]. A very recent meta-analysis reported similar correlation where the T/T genotype of $I L-1 \beta-31$ increased GC risk only in individuals with $H$. pylori infection (Table 1) [51]. A meta-analysis of $I L-1 \beta-551 \mathrm{C} / \mathrm{T}$ included 45 studies and showed that the T/T genotype could evaluate GC risk in subjects with $H$. pylori infection (OR: 1.70; 95\% CI: 1.03-2.80; $I^{2}=85 \%$ ) (Table 1) [52]. However, a meta-analysis on the IL1-RN VNTR polymorphism and GC risk showed that the IL1-RN*2 allele was associated with higher GC risk but independent of $H$. pylori infection (Table 1) [53]. Therefore, the role of genetic variants in $I L-1 \beta$ and $I L-1 R N$ in $H$. pylori-related GC needs to be clarified further.

\section{Other inflammatory cytokines}

SNPs in other inflammatory cytokines induced by $H$. pylori infection, such as $T N F-\alpha, I L-8$ and $I L-10$, are also extensively studied. Meta-analyses on the relevant studies show that the A allele of $T N F-\alpha-238 \mathrm{G} / \mathrm{A}$ [54], the A allele of $T N F-\alpha-$ $308 \mathrm{G} / \mathrm{A}$ [55], the G allele of $I L-10-1082 \mathrm{~A} / \mathrm{G}$ [9] and the $\mathrm{T}$ allele of $I L-8-251 \mathrm{~A} / \mathrm{T}$ [56] are associated with higher risk of GC (Table 1). However, the role of $H$. pylori is not sufficiently elaborated as many original studies do not report the $H$. pylori infection status of the subjects included.

\section{DNA repair}

Chronic $H$. pylori infection causes DNA damage and genetic instability in the nuclear and mitochondrial DNA of gastric mucosa cells due to inflammation (Figure 1) [59-62]. Meanwhile, $H$. pylori infection decreases the capability for DNA damage repair in the base excision repair (BER) and the mismatch repair pathways, two pathways that play an important role in maintaining the integrity of the genome [59,62-64].
Genetic variations in DNA repair genes can modulate DNA repair capacity and give rise to the accumulation of DNA damage, consequently leading to apoptosis and the unregulated proliferation of cells and then cancer. Therefore, it makes sense to study the interaction of $H$. pylori infection and variations of DNA repair gene in the development of GC.

\section{- PARP1}

PARP1, also known as adenosine diphosphate ribosyl transferase, is a crucial component of the BER system [65]. Of the numerous SNPs in the PARP1 gene region, rs1136410 at codon 762 has been extensively investigated, with a nonsynonymous $\mathrm{T} \rightarrow \mathrm{C}$ polymorphism changing the amino acid valine to alanine [57]. Miao et al. first reported that the $\mathrm{C}$ allele of rs1136410 could increase the risk of gastric cardiac cancer in a dose-dependent fashion [66]. Zhang et al. then showed that the CC genotype could increase the risk of GC jointly with $\mathrm{CagA}(+) H$. pylori infection. Silva-Fernandes et al. showed that rs1136410 in PARP1 was associated with the strains of H.pylori infected and that the C allele carriers had a higher proportion of highvirulence strains of $H$. pylori [67]. These studies suggest that the SNP could exert pressure on the bacteria and influence the outcome of the infection [67]. However, Li et al. studied the role of rs1136410 in the evolution of precancerous gastric lesions in a cohort of $1281 \mathrm{H}$. pylori-seropositive subjects and found no positive association. Other studies reported that rs1136410 was not related with GC $[68,69]$, and recently, a metaanalysis on this topic showed that rs1136410 was not associated with the risk of GC (Table 1) [57]. Given the inconsistencies, more studies are needed on the role of the PARP1 polymorphism in H. pylori-related GC.

\section{- XRCC1}

XRCC1 plays an important role in the BER pathway by interacting with a complex of DNA repair genes including DNA ligase III, polymerase beta and PARP [70-72]. Several SNPs locating in the coding or noncoding region have been reported in the associations with GC risk. Three missense variants, Arg194Trp (rs1799782, C to T) in exon 6, Arg280His (rs25489, G to A) in exon 9 and Arg399Gln (rs25487, G to A) in exon 10, have been extensively studied. The amino acid alterations may affect the protein's capability for DNA repair 


\section{Table 1. The main findings of meta-analyses cited in this review.}

\begin{tabular}{|c|c|c|c|c|c|}
\hline $\begin{array}{l}\text { First } \\
\text { author }\end{array}$ & Year & Summary site & $\begin{array}{l}\text { Studies } \\
\text { (n) }\end{array}$ & Main findings & Ref. \\
\hline \multirow[t]{7}{*}{$\begin{array}{l}\text { Persson } \\
\text { C }\end{array}$} & \multirow[t]{7}{*}{2011} & $I L-1 \beta-31 C / T$ & 32 & $\begin{array}{l}\text { Though not significant in all studies }(\mathrm{n}=32) \text {, the } \mathrm{C} \text { allele was associated with } \\
\text { reduced } \mathrm{GC} \text { risk in subgroup of Asians }(\mathrm{n}=17 ; \text { OR: } 0.86 ; 95 \% \mathrm{Cl}: 0.73-0.98 ; \\
R=1.8 \%) \text { and Asians with } H \text {. pylori positive ( } \mathrm{n}=7 \text {; OR: } 0.76 ; 95 \% \text { Cl: } 0.61-0.96 ; \\
R=2.6 \%)\end{array}$ & [9] \\
\hline & & $I L-1 \beta-511 C / T$ & 40 & $\begin{array}{l}\text { T allele was associated with reduced GC risk in subgroups of Asia high-quality } \\
\text { studies }\left(n=4 ; \text { OR: } 0.79 ; 95 \% \mathrm{Cl}: 0.64-0.97 ; I^{2}=0.0 \%\right) \text { and Asia high-quality } \\
\text { studies with H. pylori positive }\left(n=4 ; \text { OR: } 0.73 ; 95 \% \mathrm{Cl}: 0.57-0.95 ; R^{2}=0.0 \%\right)\end{array}$ & \\
\hline & & IL1-RN VNTR & 39 & $\begin{array}{l}\text { IL1- } R N^{*} 2 \text { carriers had higher risk of } \mathrm{GC}(\mathrm{n}=39 ; \mathrm{OR}: 1.17 ; 95 \% \mathrm{Cl}: 1.03-1.33 \\
R=43.6 \%) \text { and the risk is higher in carriers with H. pylori positive }(\mathrm{n}=21 ; \\
\left.\text { OR: } 1.36 ; 95 \% \mathrm{Cl}: 1.19-1.56 ; P^{2}=0.0 \%\right)\end{array}$ & \\
\hline & & IL-8-251A / T & 12 & $\begin{array}{l}\text { IL-8-251A/T was not correlated with } \mathrm{GC} \text { risk ( } \mathrm{A} \text { vs } \mathrm{C}, \mathrm{n}=12 ; \mathrm{OR}: 1.04 \text {; } \\
\text { 95\% Cl: } 0.86-1.24 ; R^{2}=60.8 \% \text { ) and neither in subgroup with } H . \text { pylori positive } \\
\left.\text { ( } \mathrm{n}=5 ; \text { OR: } 0.99 ; 95 \% \mathrm{Cl}: 0.66-1.49 ; P^{2}=75.4 \%\right)\end{array}$ & \\
\hline & & IL-10-1082A/G & 10 & $\begin{array}{l}\text { Though not significant in all studies, the } \mathrm{G} \text { allele was associated with } \\
\text { increased GC risk in subgroup of Asians ( } \mathrm{n}=5 \text {; OR: } 1.57 ; 95 \% \mathrm{Cl}: 1.14-2.16 ; \\
R=24.6 \%) \text {, Asians with } H . \text { pylori positive ( } \mathrm{n}=3 \text {; OR: } 1.82 ; 95 \% \mathrm{Cl}: 1.14-2.91 ; \\
R=0.0 \%)\end{array}$ & \\
\hline & & $T N F-\alpha-308 \mathrm{G} / \mathrm{A}$ & 21 & $\begin{array}{l}\text { The A allele was not associated with } G C \text { risk in all studies and neither in } \\
\text { subgroup with } H \text {. pylori positive }(n=10)\end{array}$ & \\
\hline & & $T N F-\alpha-238 G / A$ & 9 & $\begin{array}{l}\text { The A allele was not associated with GC risk in all studies and neither in } \\
\text { subgroup with } H \text {. pylori positive }(n=4)\end{array}$ & \\
\hline \multirow[t]{2}{*}{ Ying HY } & \multirow[t]{2}{*}{2016} & $I L-1 \beta-31 C / T$ & 37 & $\begin{array}{l}\text { IL-1 } \beta-31 C / T \text { polymorphism increased GC risk only in H. pylori-positive } \\
\text { subgroup }(n=6)\end{array}$ & [51] \\
\hline & & $I L-1 \beta-511 C / T$ & 45 & $\begin{array}{l}\text { A positive correlation was observed between the } I L-1 \beta-511 \mathrm{C} / \mathrm{T} \text { SNP and } \\
\mathrm{GC} \text { susceptibility. Subgroup analysis showed that Asian ethnicity, H. pylori } \\
\text { infection and methodologically, PCR-RFLP genotyping strengthen this } \\
\text { relationship }\end{array}$ & [52] \\
\hline Zhang Y & 2012 & IL1-RN VNTR & 71 & $\begin{array}{l}\text { This meta-analysis summarized the polymorphisms of IL1-RN VNTR and } \\
\text { IL-1 } 1 \beta+3954 C>\text { T and the predisposition to cancer risk. The IL1-RN*2 allele was } \\
\text { associated with GC risk (OR: } 1.20 ; 95 \% \mathrm{Cl}: 1.05-1.38, I^{2}=73.3 \% \text { ) and the risk was } \\
\text { higher in } H \text {. pylori-positive subgroup (OR: } 1.42 ; 95 \% \mathrm{Cl}: 1.20-1.67 ; P^{2}=35.8 \% \text { ) }\end{array}$ & [53] \\
\hline Yang JP & 2014 & $T N F-\alpha-308 \mathrm{G} / \mathrm{A}$ & 32 & $\begin{array}{l}\text { The A allele could slightly increase GC risk (OR: } 1.18 ; 95 \% \mathrm{Cl}: 1.07-1.30) \text {. The } \\
\text { independent effect adjusted for } H \text {. pylori was not calculated because very } \\
\text { limited number of studies included } H . \text { pylori infection }\end{array}$ & [54] \\
\hline Yu JY & 2013 & $T N F-\alpha-238 G / A$ & 15 & $\begin{array}{l}\text { There was a positive association between } T N F-\alpha-238 \mathrm{G} / \mathrm{A} \text { polymorphism and } \\
\text { increased GC risk (A vs G: OR: } 1.32 ; 95 \% \mathrm{Cl}: 1.02-1.72 ; R^{2}=59.8 \% \text { ). The status of } \\
\text { H. pylori infection was not taken into account }\end{array}$ & [55] \\
\hline Cheng D & 2013 & IL-8-251A/T & 18 & $\begin{array}{l}\text { The A allele carriers had higher risk for GC (OR: } 1.15,95 \% \text { Cl: } 1.03-1.29 \\
R=73 \%) \text {, but not for gastric precancerous lesions ( } \mathrm{n}=4 ; \mathrm{OR}: 1.09 ; \\
\left.95 \% \mathrm{Cl}: 0.99-1.20 ; R^{2}=0.0 \%\right) \text {. The status of } H . \text { pylori infection was not taken into } \\
\text { account }\end{array}$ & [56] \\
\hline Qin Q & 2014 & PARP-1 rs1136410 & 39 & $\begin{array}{l}\text { The } C \text { allele did not associate with GC risk ( } \mathrm{n}=4 \text {; OR: } 1.19,95 \% \mathrm{Cl}: 0.95-1.48) \text {. } \\
\text { The status of } H \text {. pylori infection was not taken into account }\end{array}$ & [57] \\
\hline Zhao DY & 2014 & $\begin{array}{l}\text { Arg194Trp, Arg280His and } \\
\text { Arg399GIn in XRCC1 }\end{array}$ & 17 & $\begin{array}{l}\text { None of the three SNPs was associated with the risk of GC. The status of } H \text {. } \\
\text { pylori infection was not taken into account }\end{array}$ & [58] \\
\hline
\end{tabular}

as these sites locate in the interaction domains with other proteins involved in BER [73]. Li et al. explored the role of Arg194Trp and Arg399Gln in the evolution of $H$. pyloriassociated precancerous lesions by following up 1281 subjects with $H$.pylori infection and they found that individuals with the 194 Arg/Trp or Trp/Trp genotype had an elevated chance of regression (OR: 1.44; 95\% CI: 1.06-1.96) whereas subjects carrying the $399 \mathrm{Arg} / \mathrm{Gln}$ or Gln/Gln genotype had a decreased probability of regression (OR: 0.68; 95\% CI: 0.49-0.92). However, another study in Japan showed no association of these two SNPs with gastric 
intestinal metaplasia, severity of histological gastritis or peptic ulcer diseases. Other studies on these three SNPs also show conflicting results [74-78]. A meta-analysis combining the relevant studies showed that none of the three SNPs were associated with the risk of GC [58] (Table 1). Moreover, studies researching the SNPs and $H$. pylori simultaneously showed no interaction in gastric carcinogenesis [74,77-78].

\section{DNA methylation}

DNA methylation is one of the most important epigenetic modulations and primarily occurs on the cytosine residues of $\mathrm{CpG}$ dinucleotides, which are frequently clustered into $\mathrm{CpG}$ islands near the $5^{\prime}$ transcription start site of genes. Methylation in $\mathrm{CpG}$ islands of the promoter regions generally suppresses the binding of transcription factors or recruits methyl-DNA-binding proteins, leading to the inactivation of gene expression. This modification is catalyzed by a group of DNA methyltransferases (DNMTs). Three main isoforms of DNMTs, DNMT1, DNMT3A and DNMT3B, have been identified so far, and the over-expressions of DNMTs have been reported to be involved in gastric cancer development and progression. Moreover, $H$. pylori infection could enhance the aberrant DNA methylation of certain genes in the gastric mucosa $[79,80]$. H. pylori-related aberrant methylation alters not only the function of common oncogenes or tumor suppressor genes but also genes involved in cell growth or differentiation and DNA repair, and therefore contributes to increasing the risk of gastric cancer [81-83]. More importantly, the increased methylation level could decrease after bacteria eradication. This association suggests that the aberrant methylation is induced by $H$. pylori infection, and $H$. pylori infection should be eradicated as early as possible $[80,83]$.

Polymorphisms of DNMTs have been reported to be associated with the susceptibility to GC [84-87]. Fan et al. found that individuals with the AA homozygous genotype of rs1550117 in the DNMT3A promoter region had a sixfold increased risk of GC compared with the GG genotype carriers and that the A allele showed a twofold higher promoter activity compared with the G allele [85]. Our study showed that the rs 1550117 AA bearers for DNMT3A have a twofold increased risk of previous infection of $H$. pylori, although we did not observe any association of rs1550117 with the risk of gastric cancer [88]. Other SNP sites of DNMT3A, including rs7560488 [87], rs36012910 [89] and rs13420827 [84], were also reported to be involved in gastric cancer risk although without consistent conclusions [84,88]. Polymorphisms of DNMTs may modify the susceptibility of GC at least partly through their role in the carcinogenesis of $H$. pylori. However, more studies are needed as only a few studies have focused on both the DNMTs and $H$. pylori infection.

\section{Conclusion}

H. pylori infection induces a host response of chronic inflammation, DNA damage and hypermethylation of certain genes. On the other hand, the host response induced by the bacteria determines the prognosis of infection. Host genetic variants in these genes could modify these effects by up- or downregulating relevant genes, as shown by $I L-1 \beta-31 \mathrm{C} / \mathrm{T}$. However, many studies on this theme do not simultaneously include H. pylori infection, and the interaction remains inconclusive.

\section{Future perspective}

H. pylori infection is responsible for most of gastric cancer. Host genetic variants could modify the process of carcinogenesis of $H$. pylori. However, many studies on the associations of the genetic variants and susceptibility to gastric cancer did not report the status of $H$. pylori infection. Therefore, $H$. pylori infection should always be taken into account in studies on susceptibility of gastric cancer in future.

\section{Financial \& competing interests disclosure}

This work was supported by National Natural Science Foundation of China (No. 81373084), the Norman Bethune Program of Jilin University (No. 2013025) and the Youth Fund of the First Hospital of Jilin University (No. JDYY42013014). The authors have no other relevant affiliations or financial involvement with any organization or entity with a financial interest in or financial conflict with the subject matter or materials discussed in the manuscript apart from those disclosed.

No writing assistance was used in the production of this manuscript.

\section{Open access}

This work is licensed under the Creative Commons Attribution-NonCommercial 4.0 Unported License. To view a copy of this license, visit http://creativecommons.org/ licenses/by-nc-nd/4.0/ 


\section{EXECUTIVE SUMMARY}

\section{Inflammation}

- Helicobacter pylori (H. pylori) induces the inflammatory response on the infected gastric epithelial cells, and inflammatory-related cytokines are upregulated.

- The cytokines play important roles in the progression of stomach inflammation and the development of gastric cancer.

\section{DNA repair}

- Chronic H. pylori infection causes genetic instability and decreases the capability for DNA damage repair in the infected gastric mucosa cell.

\section{DNA methylation}

- H. pylori infection could enhance the aberrant DNA methylation of certain gene in gastric mucosa.

\section{Conclusion}

- Polymorphisms of genes involved in H. pylori-related inflammation, DNA damage repair and aberrant DNA methylation may be associated with the risk of $H$. pylori-related gastric cancer. However, the role of these genetic variants needs to be clarified further as most of the relevant studies do not simultaneously report $H$. pylori infection.

\section{Reference}

1 Ferlay J, Soerjomataram I, Ervik M et al. GLOBOCAN $2012 \mathrm{v} 1.0$, cancer incidence and mortality worldwide: IARC cancer base No. 11. International Agency for Research on Cancer, Lyon, France (2013). http://globocan.iarc.fr

2 De Mello RA, Marques AM, Araujo A. HER2 therapies and gastric cancer: a step forward. World J. Gastroenterol. 19(37), 6165-6169 (2013).

3 Suzuki R, Shiota S, Yamaoka Y. Molecular epidemiology, population genetics, and pathogenic role of Helicobacter pylori. Infect. Genet. Evol. 12(2), 203-213 (2012).

4 Iarc. Schistosomes, liver flukes and Helicobacter pylori. IARC Working Group on the Evaluation of Carcinogenic Risks to Humans. Lyon, 7-14 June 1994. IARC Monogr. Eval. Carcinog. Risks Hum. 61, 1-241 (1994).

5 Jakszyn P, Gonzalez CA. Nitrosamine and related food intake and gastric and oesophageal cancer risk: a systematic review of the epidemiological evidence. World J. Gastroenterol. 12(27), 4296-4303 (2006).

6 Ladeiras-Lopes R, Pereira AK, Nogueira A et al. Smoking and gastric cancer: systematic review and meta-analysis of cohort studies. Cancer Causes Control 19 (7), 689-701 (2008).

7 Wroblewski LE, Peek RM Jr, Wilson KT. Helicobacter pylori and gastric cancer: factors that modulate disease risk. Clin. Microbiol. Rev. 23(4), 713-739 (2010).

8 Uemura N, Okamoto S, Yamamoto S et al. Helicobacter pylori infection and the development of gastric cancer. $N$. Engl. J. Med. 345(11), 784-789 (2001).

9 Persson C, Canedo P, Machado JC, El-Omar EM, Forman D. Polymorphisms in inflammatory response genes and their association with gastric cancer: a HuGE systematic review and meta-analyses. Am. J. Epidemiol. 173(3), 259-270 (2011).

10 Wang F, Meng W, Wang B, Qiao L. Helicobacter pylori-induced gastric inflammation and gastric cancer. Cancer Lett. 345(2), 196-202 (2014).

11 Sepulveda AR. Helicobacter, inflammation, and gastric cancer. Curr Pathobiol. Rep. 1(1), 9-18 (2013).

12 Tu S, Bhagat G, Cui G et al. Over expression of interleukin-1beta induces gastric inflammation and cancer and mobilizes myeloid-derived suppressor cells in mice. Cancer Cell 14(5), 408-419 (2008).

13 El-Omar EM, Carrington M, Chow WH et al. Interleukin-1 polymorphisms associated with increased risk of gastric cancer. Nature 404(6776), 398-402 (2000).

14 El-Omar EM, Rabkin CS, Gammon MD et al. Increased risk of noncardia gastric cancer associated with proinflammatory cytokine gene polymorphisms. Gastroenterology 124(5), 1193-1201 (2003).

15 Machado JC, Pharoah P, Sousa S et al. Interleukin $1 \mathrm{~B}$ and interleukin $1 \mathrm{RN}$ polymorphisms are associated with increased risk of gastric carcinoma. Gastroenterology 121(4), 823-829 (2001).

16 Figueiredo C, Machado JC, Pharoah P et al. Helicobacter pylori and interleukin 1 genotyping: an opportunity to identify high-risk individuals for gastric carcinoma. J. Natl Cancer Inst. 94(22), 1680-1687 (2002).

17 Hwang IR, Kodama T, Kikuchi S et al. Effect of interleukin 1 polymorphisms on gastric mucosal interleukin 1beta production in Helicobacter pylori infection. Gastroenterology 123(6), 1793-1803 (2002).

18 Furuta T, El-Omar EM, Xiao F, Shirai N, Takashima M, Sugimura H. Interleukin 1beta polymorphisms increase risk of hypochlorhydria and atrophic gastritis and reduce risk of duodenal ulcer recurrence in Japan. Gastroenterology 123(1), 92-105 (2002).

19 Chang YT, Wu MS, Shun CT, Lin MT, Chang MC, Lin JT. Association of polymorphisms of interleukin-1 beta gene and Helicobacter pylori infection with the risk of gastric ulcer. Hepatogastroenterology 49(47), 1474-1476 (2002).

20 Zeng ZR, Hu PJ, Hu S et al. Association of interleukin 1B gene polymorphism and gastric cancers in high and low prevalence regions in China. Gut 52(12), 1684-1689 (2003).

21 Chen A, Li CN, Hsu PI et al. Risks of interleukin-1 genetic polymorphisms and Helicobacter pylori infection in the development of gastric cancer. Aliment. Pharmacol. Ther. 20(2), 203-211 (2004).

22 Al-Moundhri MS, Al-Nabhani M, Al-Bahrani B et al. Interleukin-1beta gene $(I L-1 B)$ and interleukin 1 receptor antagonist gene $(I L-1 R N)$ polymorphisms and gastric cancer risk in an Omani Arab population. Gastric Cancer 9(4), 284-290 (2006). 
23 Chang YW, Jang JY, Kim NH et al. Interleukin-1B $(I L-1 B)$ polymorphisms and gastric mucosal levels of IL-1beta cytokine in Korean patients with gastric cancer. Int. J. Cancer 114(3), 465-471 (2005).

24 Gatti LL, Burbano RR, De Assumpcao PP, Smith Mde A, Payao SL. Interleukin-1beta polymorphisms, Helicobacter pylori infection in individuals from Northern Brazil with gastric adenocarcinoma. Clin. Exp. Med. 4(2), 93-98 (2004).

25 Gonzalez-Hormazabal P, Musleh M, Bustamante $\mathrm{M}$ et al. Role of cytokine gene polymorphisms in gastric cancer risk in Chile. Anticancer Res. 34(7), 3523-3530 (2014).

26 Hartland S, Newton JL, Griffin SM, Donaldson PT. A functional polymorphism in the interleukin-1 receptor-1 gene is associated with increased risk of Helicobacter pylori infection but not with gastric cancer. Dig. Dis. Sci. 49(9), 1545-1550 (2004).

27 Leung WK, Chan MC, To KF et al. H. pylori genotypes and cytokine gene polymorphisms influence the development of gastric intestinal metaplasia in a Chinese population. Am. J. Gastroenterol. 101(4), 714-720 (2006).

28 Li C, Xia HH, Xie W et al. Association between interleukin-1 gene polymorphisms and Helicobacter pylori infection in gastric carcinogenesis in a Chinese population. J. Gastroenterol. Hepatol. 22(2), 234-239 (2007).

29 Melo Barbosa HP, Martins LC, Dos Santos SE et al. Interleukin-1 and TNF-alpha polymorphisms and Helicobacter pylori in a Brazilian Amazon population. World J. Gastroenterol. 15(12), 1465-1471 (2009).

30 Palli D, Saieva C, Luzzi I et al. Interleukin-1 gene polymorphisms and gastric cancer risk in a high-risk Italian population. Am. J. Gastroenterol. 100(9), 1941-1948 (2005).

31 Perri F, Piepoli A, Bonvicini C et al. Cytokine gene polymorphisms in gastric cancer patients from two Italian areas at high and low cancer prevalence. Cytokine 30(5), 293-302 (2005).

32 Rocha GA, Guerra JB, Rocha AM et al. $I L I R N$ polymorphic gene and cagA-positive status independently increase the risk of noncardia gastric carcinoma. Int. J. Cancer 115(5), 678-683 (2005).

33 Ruzzo A, Graziano F, Pizzagalli F et al. Interleukin $1 \mathrm{~B}$ gene $(I L-1 B)$ and interleukin 1 receptor antagonist gene $(I L-1 R N)$ polymorphisms in Helicobacter pylori-negative gastric cancer of intestinal and diffuse histotype. Ann. Oncol. 16(6), 887-892 (2005).

34 Sicinschi LA, Lopez-Carrillo L, Camargo MC et al. Gastric cancer risk in a Mexican population: role of Helicobacter pylori CagA positive infection and polymorphisms in interleukin-1 and -10 genes. Int. J. Cancer 118(3), 649-657 (2006).

35 Sitarz R, De Leng WW, Polak M et al. IL-1B $-31 \mathrm{~T}>\mathrm{C}$ promoter polymorphism is associated with gastric stump cancer but not with early onset or conventional gastric cancers. Virchows Arch. 453(3), 249-255 (2008).

36 Wang XQ, Terry PD, Cheng L et al. Interactions between pork consumption, CagA status and IL-1B-31 genotypes in gastric cancer. World J. Gastroenterol. 20(25), 8151-8157 (2014).

37 Yang J, Hu Z, Xu Y et al. Interleukin-1B gene promoter variants are associated with an increased risk of gastric cancer in a Chinese population. Cancer Lett. 215(2), 191-198 (2004).

38 Zambon CF, Basso D, Navaglia F et al. Pro- and anti-inflammatory cytokines gene polymorphisms and Helicobacter pylori infection: interactions influence outcome. Cytokine 29(4), 141-152 (2005).

39 Zhang WH, Wang XL, Zhou J, An LZ, Xie XD. Association of interleukin-1B $(I L-1 B)$ gene polymorphisms with risk of gastric cancer in Chinese population. Cytokine 30(6), 378-381 (2005).

40 Duraes C, Munoz X, Bonet C et al. Genetic variants in the $I L 1 A$ gene region contribute to intestinal-type gastric carcinoma susceptibility in European populations. Int. J. Cancer 135(6), 1343-1355 (2014).

41 Garcia-Gonzalez MA, Lanas A, Quintero E et al. Gastric cancer susceptibility is not linked to pro-and anti-inflammatory cytokine gene polymorphisms in whites: a Nationwide Multicenter Study in Spain. Am. J. Gastroenterol. 102(9), 1878-1892 (2007).

$42 \mathrm{He} \mathrm{C}$, Tu H, Sun L et al. Helicobacter pylori-related host gene polymorphisms associated with susceptibility of gastric carcinogenesis: a two-stage case-control study in Chinese. Carcinogenesis 34(7), 1450-1457 (2013).

43 Hnatyszyn A, Wielgus K, Kaczmarek-Rys M et al. Interleukin-1 gene polymorphisms in chronic gastritis patients infected with Helicobacter pylori as risk factors of gastric cancer development. Arch. Immunol. Ther. Exp. (Warsz.) 61(6), 503-512 (2013).

44 Kutikhin AG, Yuzhalin AE, Volkov AN, Zhivotovskiy AS, Brusina EB. Correlation between genetic polymorphisms within $I L-1 B$ and TLR4 genes and cancer risk in a Russian population: a case-control study. Tumour Biol. 35(5), 4821-4830 (2014).
45 Lakhanpal M, Yadav DS, Devi TR et al. Association of interleukin-1beta $-511 \mathrm{C} / \mathrm{T}$ polymorphism with tobacco-associated cancer in northeast India: a study on oral and gastric cancer. Cancer Genet. 207(1-2), 1-11 (2014).

46 Lee KA, Park JH, Sohn TS, Kim S, Rhee JC, Kim JW. Interaction of polymorphisms in the interleukin 1B-31 and general transcription factor $2 \mathrm{~A} 1$ genes on the susceptibility to gastric cancer. Cytokine 38(2), 96-100 (2007).

47 Persson C, Engstrand L, Nyren O et al. Interleukin 1-beta gene polymorphisms and risk of gastric cancer in Sweden. Scand. J. Gastroenterol. 44(3), 339-345 (2009).

48 Qiu B, Zou HY, Yang YH, Lai CF. Interleukin-1B-31 gene polymorphism in Hakka gastric cancer patients in Guangdong, China. Genet. Mol. Res. 13(3), 5873-5879 (2014).

49 Zeng XF, Li J, Li SB. A functional polymorphism in IL-1A gene is associated with a reduced risk of gastric cancer. Tumour Biol. 35(1), 265-268 (2014).

50 Zhao JD, Geng PL, Li ZQ et al. Associations between interleukin-1 polymorphisms and gastric cancers among three ethnicities. World J. Gastroenterol. 18(47), 7093-7099 (2012).

51 Ying HY, Yu BW, Yang Z et al. Interleukin-1B $31 \mathrm{C}>\mathrm{T}$ polymorphism combined with Helicobacter pylori-modified gastric cancer susceptibility: evidence from 37 studies. J. Cell. Mol. Med. 20(3), 526-536 (2016).

52 Park MJ, Hyun MH, Yang JP, Yoon JM, Park S. Effects of the interleukin-1beta-511 C/T gene polymorphism on the risk of gastric cancer in the context of the relationship between race and $\mathrm{H}$. pylori infection: a meta-analysis of 20,000 subjects. Mol. Biol. Rep. 42(1), 119-134 (2015).

53 Zhang Y, Liu C, Peng H, Zhang J, Feng Q. IL1 receptor antagonist gene IL1-RN variable number of tandem repeats polymorphism and cancer risk: a literature review and metaanalysis. PLoS ONE 7(9), e46017 (2012).

54 Yang JP, Hyun MH, Yoon JM, Park MJ, Kim D, Park S. Association between TNFalpha-308 G/A gene polymorphism and gastric cancer risk: a systematic review and meta-analysis. Cytokine 70(2), 104-114 (2014).

55 Yu JY, Li L, Ma H et al. Tumor necrosis factor-alpha $238 \mathrm{G} / \mathrm{A}$ polymorphism and gastric cancer risk: a meta-analysis. Tumour Biol. 34(6), 3859-3863 (2013).

56 Cheng D, Hao Y, Zhou W, Ma Y. Positive association between interleukin-8 -251A > T polymorphism and susceptibility to gastric 
carcinogenesis: a meta-analysis. Cancer Cell Int. 13(1), 100 (2013).

57 Qin Q, Lu J, Zhu $\mathrm{H}$ et al. PARP-1 Val762Ala polymorphism and risk of cancer: a meta-analysis based on 39 case-control studies. PLoS ONE 9(5), e98022 (2014).

58 Zhao DY, Cheng L, Yu J, Shen H. XRCC1 genetic polymorphism Arg339Gln, Arg194Trp, Arg280His and gastric cancer risk: an evidence based decision. Cancer Biomark. 14(6), 449-456 (2014).

59 Machado AM, Figueiredo C, Touati E et al. Helicobacter pylori infection induces genetic instability of nuclear and mitochondrial DNA in gastric cells. Clin. Cancer Res. 15(9), 2995-3002 (2009).

60 Machado AM, Figueiredo C, Seruca R, Rasmussen LJ. Helicobacter pylori infection generates genetic instability in gastric cells. Biochim. Biophys. Acta 1806(1), 58-65 (2010).

61 Toller IM, Neelsen KJ, Steger M et al. Carcinogenic bacterial pathogen Helicobacter pylori triggers DNA double-strand breaks and a DNA damage response in its host cells. Proc. Natl Acad. Sci. USA 108(36), 14944-14949 (2011).

62 Park DI, Park SH, Kim SH et al. Effect of Helicobacter pylori infection on the expression of DNA mismatch repair protein. Helicobacter 10(3), 179-184 (2005).

63 Kim JJ, Tao H, Carloni E, Leung WK, Graham DY, Sepulveda AR. Helicobacter pylori impairs DNA mismatch repair in gastric epithelial cells. Gastroenterology 123(2), 542-553 (2002).

64 Kidane D, Murphy DL, Sweasy JB. Accumulation of abasic sites induces genomic instability in normal human gastric epithelial cells during Helicobacter pylori infection. Oncogenesis 3, e128 (2014).

65 Reynolds P, Cooper S, Lomax M, O'neill P. Disruption of PARP1 function inhibits base excision repair of a sub-set of DNA lesions. Nucleic Acids Res. 43(8), 4028-4038 (2015).

66 Miao X, Zhang X, Zhang L et al. Adenosine diphosphate ribosyl transferase and $\mathrm{x}$-ray repair cross-complementing 1 polymorphisms in gastric cardia cancer. Gastroenterology 131(2), 420-427 (2006).

67 Silva-Fernandes IJ, Da Silva TA, Agnez-Lima LF, Ferreira MV, Rabenhorst SH. Helicobacter pylori genotype and polymorphisms in DNA repair enzymes: where do they correlate in gastric cancer? J. Surg. Oncol. 106(4), 448-455 (2012).
68 Pan XF, Xie Y, Loh M et al. Polymorphisms of XRCC1 and ADPRT genes and risk of noncardia gastric cancer in a Chinese population: a case-control study. Asian Pac. J. Cancer Prev. 13(11), 5637-5642 (2012).

69 Wen YY, Pan XF, Loh M et al. ADPRT Val762Ala and XRCC1 Arg194Trp polymorphisms and risk of gastric cancer in Sichuan of China. Asian Pac. J. Cancer Prev. 13(5), 2139-2144 (2012).

70 Vidal AE, Boiteux S, Hickson ID, Radicella JP. XRCC1 coordinates the initial and late stages of DNA abasic site repair through protein-protein interactions. $E M B O \mathrm{~J}$. 20(22), 6530-6539 (2001).

71 Parsons JL, Dianova Ii, Allinson SL, Dianov GL. DNA polymerase beta promotes recruitment of DNA ligase III alpha-XRCC1 to sites of base excision repair. Biochemistry 44(31), 10613-10619 (2005).

72 Petermann E, Keil C, Oei SL. Roles of DNA ligase III and XRCC1 in regulating the switch between short patch and long patch BER. DNA Repair (Amst.) 5(5), 544-555 (2006).

73 Yin M, Hu Z, Tan D, Ajani JA, Wei Q. Molecular epidemiology of genetic susceptibility to gastric cancer: focus on single nucleotide polymorphisms in gastric carcinogenesis. Am. J. Transl. Res. 1(1), 44-54 (2009).

74 Shen H, Xu Y, Qian Y et al. Polymorphisms of the DNA repair gene XRCC1 and risk of gastric cancer in a Chinese population. Int. J. Cancer 88(4), 601-606 (2000).

75 Lee SG, Kim B, Choi J, Kim C, Lee I, Song $\mathrm{K}$. Genetic polymorphisms of XRCC1 and risk of gastric cancer. Cancer Lett. 187(1-2), 53-60 (2002).

76 Duarte MC, Colombo J, Rossit AR et al. Polymorphisms of DNA repair genes XRCC1 and $X R C C 3$, interaction with environmental exposure and risk of chronic gastritis and gastric cancer. World J. Gastroenterol. 11(42), 6593-6600 (2005).

77 Capella G, Pera G, Sala N et al. DNA repair polymorphisms and the risk of stomach adenocarcinoma and severe chronic gastritis in the EPIC-EURGAST study. Int. J. Epidemiol. 37(6), 1316-1325 (2008).

78 Palli D, Polidoro S, D’Errico M et al. Polymorphic DNA repair and metabolic genes: a multigenic study on gastric cancer. Mutagenesis 25(6), 569-575 (2010).

79 Nakajima T, Yamashita S, Maekita T, Niwa T, Nakazawa K, Ushijima T. The presence of a methylation fingerprint of Helicobacter pylori infection in human gastric mucosae. Int. J. Cancer 124(4), 905-910 (2009).

80 Shin CM, Kim N, Lee HS et al. Changes in aberrant DNA methylation after Helicobacter pylori eradication: a long-term follow-up study. Int. J. Cancer 133(9), 2034-2042 (2013).

$81 \mathrm{Na} \mathrm{HK}$, Woo JH. Helicobacter pylori induces hypermethylation of $\mathrm{CpG}$ islands through upregulation of DNA methyltransferase: possible involvement of reactive oxygen/ nitrogen species. J. Cancer Prev. 19(4), 259-264 (2014).

82 Wang Y, Huang LH, Xu CX et al. Connexin 32 and 43 promoter methylation in Helicobacter pylori-associated gastric tumorigenesis. World J. Gastroenterol. 20(33), 11770-11779 (2014).

83 Alvarez MC, Santos JC, Maniezzo N et al. $M G M T$ and $M L H 1$ methylation in Helicobacter pylori-infected children and adults. World J. Gastroenterol. 19(20), 3043-3051 (2013).

84 Yang XX, He XQ, Li FX, Wu YS, Gao Y, Li M. Risk-association of DNA methyltransferases polymorphisms with gastric cancer in the southern chinese population. Int. J. Mol. Sci. 13(7), 8364-8378 (2012).

85 Fan H, Liu D, Qiu X et al. A functional polymorphism in the DNA methyltransferase- $3 \mathrm{~A}$ promoter modifies the susceptibility in gastric cancer but not in esophageal carcinoma. BMC Med. 8, 12 (2010).

$86 \mathrm{Hu}$ J, Fan H, Liu D, Zhang S, Zhang F, Xu H. DNMT3B promoter polymorphism and risk of gastric cancer. Dig. Dis. Sci. 55(4), 1011-1016 (2010).

87 Wu H, Zhang K, Gong P et al. A novel functional TagSNP Rs7560488 in the DNMT3A1 promoter is associated with susceptibility to gastric cancer by modulating promoter activity. PLoS ONE 9(3), e92911 (2014).

88 Cao XY, Jia ZF, Cao DH et al. DNMT3a rs1550117 polymorphism association with increased risk of Helicobacter pylori infection. Asian Pac. J. Cancer Prev. 14(10), 5713-5718 (2013).

89 Wu Q, Lu S, Wang L et al. DNMT3A rs36012910 A>G polymorphism and gastric cancer susceptibility in a Chinese population. Mol. Biol. Rep. 39(12), 10949-10955 (2012). 